\title{
Book Review: Malcolm
}

\section{Cook \& Kirsten Moana}

Thompson (eds.), Animation

and Advertising, (Palgrave

Macmillan, 2019)

\section{REVIEW}

JEANNETTE STRICKLAND (D)

ब나

Open Library of Humanities

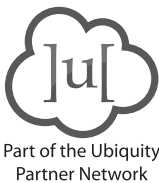

Part of the Ubiquity

CORRESPONDING AUTHOR:

Jeannette Strickland

University of Liverpool, GB

J.Strickland2@liverpool.ac.uk

KEYWORDS:

Animation; advertising; George Pal; Lotte Reiniger

TO CITE THIS ARTICLE:

Strickland, J. 2021. Book

Review: Malcolm Cook \&

Kirsten Moana Thompson

(eds.), Animation and

Advertising, (Palgrave

Macmillan, 2019). Open

Screens, 4(1): 15, pp. 1-3. DOI:

https://doi.org/10.16995/os.67 


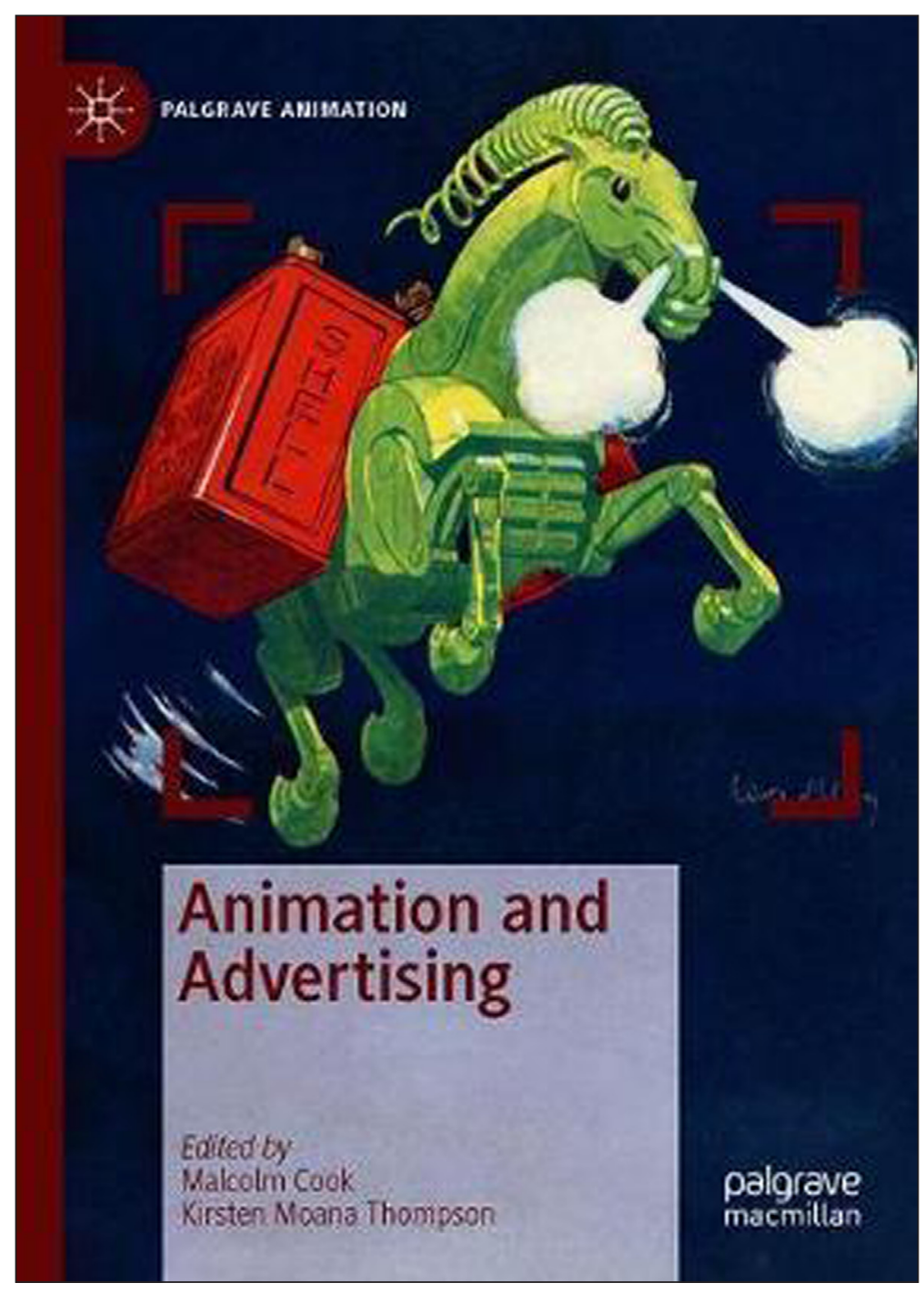

Studies of animation have tended to focus on the genre as a form of art or entertainment and, whilst myriad publications abound relating to the history of advertising, the use of animation in advertising is still an under-researched area. The key role that animation as a marketing technique has played, and continues to play, is, therefore, one that the editors of this volume aim to address. They situate animation in a diverse media environment that encompasses the influences of print, radio, digital, Japanese anime and even theme parks. Part of a series by Palgrave to showcase new research in the interdisciplinary field of animation, Malcolm Cook and Kirsten Moana Thompson's volume is the first book to address the topic of animated advertising from a global perspective. It comprises an introductory essay and fifteen case studies arranged in five themed sections, each with its own bibliography, although some of the bibliographies are more comprehensive than others. Whilst the first half of the book focuses more on animated advertising in the cinema, the second covers the television and digital eras, examining the rise of specialist studios and the role of animated advertising in the development of computer graphics. There is a useful separate index of film titles and the illustrations are well-chosen.

The introductory essay presents an overview of the use of animation in advertising throughout the last one hundred and twenty years. There is only the briefest introduction to the earliest days of cinema animation in the silent era, however, even though Cook has already published a book on the topic. ${ }^{1}$ Instead, from the following case studies, the story of animated advertising starts in the 1920s. Nevertheless, the book highlights the myriad ways in which animation has been used and the diverse range of organisations that have employed it as a marketing technique, exploring the role of animation in shaping our consumer choices and how animation itself was shaped by its use as an advertising medium. The case studies uncover some untold or forgotten stories. Many of the earlier protagonists were émigrés fleeing the advance of Nazism, including George Pal. As Mette Peters relates, though better known for his work in science fiction after he emigrated to America in 1939, Pal started out by creating animated advertisements in Europe for Philips (the electrical goods manufacturers) and Horlick's malted milk. The importance of animators 
as experimenters with new technologies is highlighted throughout: Pal experimented with the use of colour, an added attraction in advertising films, and his refinement of the stop-motion technique is still used by studios today.

A fresh light is also shone on Lotte Reiniger's work for the British GPO in the 1930s by Tashi Petter. Reiniger used hand-cut silhouettes and drew on elements of folklore and fairy tales from her background, but she played down the importance of this commissioned work, and the films she made have been overlooked until now. Meanwhile, Paul Wells argues that Nike's melding of athletes with cartoons has created 'secular folk-tales' in which animation is 'physical activity as art' and its use in advertising appeals to both children and adults looking back fondly on the cartoons of their youth.

Cross-overs between different media, with the use of film stills in print advertisements, for example, run as another theme through the chapters, as does the development of cartoon characters that became symbolic of the products they promoted, such as Norihei for food manufacturer Momoya, Uncle Boby (Schicht company), or Reddy Kilowatt. As Lilly Husbands reasons, MTV's computer-generated animation of its logo in the 'idents' between music videos became an advertisement for MTV itself. Even the Disney Corporation - and, later, Pixar - were not immune from making animated advertisements for other companies. In a mutually beneficial arrangement with Richfield Oil Corporation in the 1950s, Disney comic books were given away at its petrol stations. Cook re-evaluates this work, which has previously been viewed as inconsequential, arguing that it had lasting impact on Disney's approach to promotion and sponsorship even though the unit was operational for only ten years. For Pixar it provided valuable income in a time of economic uncertainty, but animated advertising also offered a space in which to experiment and present everyday objects from different perspectives.

This book goes a long way to telling the story of an overlooked element of both the film and advertising industries and adds greatly to our understanding and knowledge, but there is clearly far more to be explored and discovered. The content, for example, covers a widerange of countries including India and Japan, but it is surprising that none of the chapters includes anything from the African continent where animation is part of the growing creative economy. Nevertheless, it is hoped that these case studies will act as a catalyst to spark more interest and research in this field.

\section{NOTE}

1 Malcolm Cook, Early British animation: From page and stage to cinema screens (Palgrave Macmillan, 2018).

\section{COMPETING INTERESTS}

The author has no competing interests to declare.

\section{AUTHOR AFFILIATION}

Jeannette Strickland (D) orcid.org/0000-0001-7141-7450

University of Liverpool, GB

TO CITE THIS ARTICLE:

Strickland, J. 2021. Book Review: Malcolm Cook \& Kirsten Moana Thompson (eds.), Animation and Advertising, (Palgrave Macmillan, 2019). Open Screens, 4(1): 15, pp. 1-3. DOI: https://doi.org/10.16995/os.67

Submitted: 01 May 2021 Accepted: 01 May 2021 Published: 07 June 2021

COPYRIGHT:

(C) 2021 The Author(s). This is an open-access article distributed under the terms of the Creative Commons Attribution 4.0 International License (CC-BY 4.0), which permits unrestricted use, distribution, and reproduction in any medium, provided the original author and source are credited. See http://creativecommons.org/licenses/by/4.0/.

Open Screens is a peer-reviewed open access journal published by Open Library of Humanities.

\section{స나 ॰}

